\title{
Suggestions for the Land Transport Service of the Army
}

\section{George G. Beazley}

To cite this article: George G. Beazley (1869) Suggestions for the Land Transport Service of the Army, Royal United Services Institution. Journal, 13:56, 564-575, DOI: 10.1080/03071846909417033

To link to this article: http://dx.doi.org/10.1080/03071846909417033

册 Published online: 25 Sep 2009.

Submit your article to this journal $\pi$

Џll Article views: 6

Q View related articles $\square$ 


\title{
SUGGESTIONS FOR TIE LAND TRANSPORT SERVICF OF THE ARMY.
}

\author{
By George G. Beazlex, Captain 83rd Regiment.
}

\begin{abstract}
"A reteran army indecd, kept constantly leady for marching is erpensire, jet it gires a Stato tle disposal of things among its ncirhbours, or at Iesst procures it a great reputation in other respects."

"It was a just nnswer of Solon to Crcesus, who showed line all his treasure: ' Yes, sir, but if nnotler should come with better iron than you, ho would bo master of all this gold."
\end{abstract}

LORD Bicos.

So many schemes connected with tho management of the $\Lambda \mathrm{rmy}$ hare lately been proposed and discussed, that it would seem almost needless to bring forward another. They have, horrever, chiefly referred to the subject of recruiting. This has been pretty well exhausted. Most persons who havo attentively considered the matter hare probably arrived at the conclusion that we can only competo with the armaments of the Continent by the introduction of a modified conscription, and the gradual abolition of the militia, jeomaury, and voluntecrs for a really effectivo Reserve, composed of men who have serred a fer years in tho regular $\Lambda$ rmy.

The object of the present paper is not to treat of recruiting, but to deal with the equally important subject of transport, touching incidentally on tho defence of this country-rital questions, on whatever system inen may be raised for military service. Tho British Army, though in many respects well organized, stops short of completion. Wo hare regiments perfectly drilled and equipped; yet beyond their clotles, arms, and accontrements, they have littlo that they require in the field. To move them entails numerous returus and much correspondence. To collect and place even a small force in the ficld to meet tho enemy would, as there is littlo or nothing ready in the way of transport, be a matter of some dificulty. To obviate this defect, and remore the attendant delay and uncertainty, is the aim of the following plan.

Any proposal connected with the organization of an Army divides itself into tro distinct branches, namely, the organization required for war, and that required for pence.

Although the former is the really inportant brancl, yet peace being the normal condition of armies, it is impossible to deviso a plau for 
the one without considering tho other. Tho question then is, how to be prepared for war at a moment's notice, without unnecessarily depriving Oficers and men, during peace, of the ordinary advantages and comforts enjoyed by the citizen.

The outline plan which follows, applies chicfly to the Infantry; but, with certain self-evident modifications, includes the other arms of tho Service, aud is intended, in a great measure, as the basis of a scliemo to ensure this country against surpriso by invasion.

Since the regimental system of the British Army has been pronounced perfect as far as it gocs, and since it is the system the most suitable to our wants, why not, instead of engrafting upon it modifications of Continental plans, cudeavour to render it complete?

The Unit.-It is therefore proposed that the regiment should be made the unit of efficiency. 'I'hat all transport, certainly of the first reservo of stores, and second of ammunition, should be organized ulon a system based on tho requirements of a regiment, and not on the wants of a brigade or larger unfixed unit.

To carry out the above idea, a regriment must bo a fixed, distinct, and independent body, self-reliant for (1) trausport, (2) food, (3) shelter, (4) clothing, (5) regimental and first reservo of ammunition, and (6) hospital.

Reginental Train.-Whe first thing to be provided is transport. In this country wagrons are the most suitable. 'Theso waggons should be so constructed that withont unloading they could travel on tho railway trucks. As they wonld bo in charge of the regiment, they should he marked with its number, the letter of the company or companies, or namo of the department to which they belong. On the march they would follow the regineut, brigade, or division, in charge of men of the regiment, who should walk or drive, but not ride.

The minimum amount of tentage, baggrago of Officcrs, tools and implements, arm chests, squal bags, reserve ammunition and impeclimenta, includingr regimental hospital equipment, absolutely required in the field, would hare to bo fixed as to size, shape, and rejght. These points heing settled, the number of waggons to bo allotted to cach regiment rould be determined.

In time of peace, contractors would supply the horses and harness at fixed rates, and possibly the same arrangement might be the most economical in time of war. Gast artillery, and cavalry horses, which sell for little or nothing; might bo mado available, if it wero considered desirable to maintain tho nucleus of an independent system; ono or two horses to a regiment, for instance. Oxen should not bo orcrlooked; they cust less, require little harness, movo fast enough, are easily onneyed by railway, and when old, or in case of emergency, could bo oaten. How far the employment of traction-engines could be used with adrantage might le worthy of experiment.

It has bou urged that waggons would not be required in Engrand, os the railroads would furnish all the necessary conveyauce. Thourgl railroads would greatly facilitate the movements and concentration of troops, it is clear that were the line, bridges, or viaducts destroyed, or the post to be occupied only a shoit distance from the station, it would 2 P 2 
be absolutely necessary to have the baggage brought up. For real efficiency, therefore, it may be assumed that the raggrons could not be dispensed with.

To diminish the baggage now carried about by Officers, barrackrooms should be furnished with all the articles required beyond tho' ordinary field kit.

All private baggage in time of peace should be moved independently of the regiment, by private carriers, as at present.

Food.-Instead of butchers and bakers being formed into one corps under a ciril department, each regiment should hare its own, liable to do military duty when not required in the exercise of their trades. 'These men would work in regimental, brigade, or divisional abattoirs and bakeries, receiving while so employed substantial working pay. In the event of misconduct, or the departure of a corps, all men so engaged away from their regiments, would rejoin.

Regimental Clothing.-A moderate supply of the most essential articles (such as boots, gaiters, socks, and flannel shirts) should accompany the regiment, a minimum being fixed for field service. These would hare to be replenished as opportunities offered. The bulk of the Quartermaster's stores, would, in time of peace, have to move with the private baggage, or be left in charge of the depôt on the regiment going under canvas.

Regimental Ammunition.-The regimental reserve of ammunition (30 rounds per man), which might with advantage be considerably increased, should be divided among, and carried with the company's baggage, unless the regulation-means were provided.

The first reserve of small-arm-ammunition, now carried by the Royal Artillery, should bo in a separate waggon, containing the necessary means for distributing it in difficult ground.

Regimental Mospital.-Medical Officers should be formed into one corps, and one, two, or three, according to the exigencies of the Service, attached to a regiment. The hospital should be entircly regimental, and all drugs, instruments, stores, and comforts should be drawn direct from the medical stores by the Surgeon doing duty with the regiment.

Though the Surgeon would not belong to the regiment, or adopt its uniform, he would be under the orders of the Commanding Officer, and in every way responsible for the thorough efficiency of his own department.

General Hospital.- Wounded men, and men too sick to trarel, would, as now, be left in General Hospitals, established in garrison towns, or at the different depôts on the lines of communication. Only the Regimental Hospital, with the simplest cases, should more with the troops.

The Army Hospital Corps should be disbanded, their duties being always performed in regimental hospitals by trained soldiers of the regiment; in General Ilospitals in garrison towns (during peace) by similar men from the several corps serving therein; in war time, by civilians, men or women, supplemented br disabled and convalescent soldiers.

In order to obviate any inconvenience which might arise from sick- 
ness, misconduct, or furlougl, overy regiment should have a considerable number of men trained as drivers, butchers, bakers, and hospital orderlies. The last, as well as all bandsmen, should be trained at Netley, and be thoroughly instructed in ambulance duties. All such inen, when thus employed, should receiro a moderato daily sum, in addition to their pay.

So much for the regimental arrangements. Should such a scheme, or a modification of it, erer be adopted, it is erident that the responsibility of Officers commanding regiments and companies would be materially increased. Every Officer commanding a regiment would bo bound to kcep it fully equipped, and up to the regulation standard of efficiency. For this purpose he should communicate directly with all the departments of supply in all matters not involving maintenance, exchange, or expenditure beyond the recognized equipment.

Supply Departments.-The Supply Departments are the Commissariat, the Store, the Paymasters, the Barrack, the Purveyors, and the Medical.

In view of the proposed plan, the union of the first four departments under what is termed the "Control System" would not be desirable; they should bo kept separate. Their duties are perfectly distinct; they have nothing in common. A Controller is only acquainted with the department to which he originally belonged; consequently, when referred to on a subject ont of that sphere, he would be obliged to forward the correspondence to the branch of the control concerned. Thus, in most cases, the control system would only add another channel of communication to those already in existence. The only real control required would be that exercised by the TVar Office on the part of the Treasury. The Ofticers of the supply departments, therefore, while under the anthority of the senior combatant Officer for the correct discharge of their duties generally, should-both for the benefit of the public purse and their own support and security-be accountable to the War Office for their expenditure. To prevent unnecessary reference, a clear code of regulations should bo drawn up for the guidance of each department, and the Army generally. Such rules would, however, be liable to be set aside by General or other Officers commanding independent bodies of troops during war.

Paymaster's or Accountant's Department.-The Paymaster's Departwent, representing, and communicating directly with the TVar Office, vould hare sole charge of the financial arrangements and the military - test. From it, as from a bank, all money required by Regimental aymasters, or departments, should be drawn.

The Purveyor's Department.-The Purveyor's Department should be - molished, and the duties of these officers, as far as the care and dis- ibution of medicines and comforts are concerned, be entrusted to - mical officers of different grades, on additional or Staff pay. This - ould tend to the unity of the Medical Department.

The Barrack Department.- - However opinions may differ as to the - Ivisability of bringing several distinct departments under one head, - were can be little doubt that, for such a scheme as the present, the 
Barrack Department should bo retained as a separate branch of the Service. Although barracks might, and indeed would be, frequently occupied in time of war by the regulars or reserves, they are, nevertheless, the natural homo of tho soldier during peace. Here the recreation-rooms, libraries, schools, workshops, and canteens are established. These cannot, even in a modified form, accompany the troops on active service; they, with the barracks, are stationary, and aro pre-eminently adapted only to peaceful times. The Commissariat, Store, Medical, and Paymaster's Departments, on the other hand, must be with the troops, whether in barracks or in the field. This distinction seems to point clearly to the necessity of maintaining the integrity of the Barrack Department as a separato cstablishment. This principle admitted, it would bo desirnble that the Barrackmasters should bo selected from Engineer or other Officers, who having a taste and aptitude for construction, might bo willing, for the sake of a fixed home, to relinquish their military carcer-retaining, however, if they wished it, honorary rank.

They should have chargo of all permanent military buildings and property, including hospitals, libraries, schools, books, recreationrooms, canteens, furniture, and all implements not required in the field. The construction of new barracks, all additions to, improvements and repairs of old, slould be carried out by them, either by contract or military labour.

Thus the Officer of Engineers would be reliered of all duties connected with the construction and repair of barracks, and be enabled to keep up the special knowledge required of him on service.

There should be a store in overy barrack for the private baggage of Officers, and tho surplus of Officers' and Serjeants' messes; so that when the regiment encamped for the periodical summer drill, the rooms might be handed over to the Barrack-master either for repairs or for the occupation of another regiment.

Departmental Trains.-The Regimental Trains having been provided for, we now come to the consideration of the transport required by the different departments attached to the Army. This should be divided into the following branches:-

1. The Store Train, including (a) Artillery reserve stores and ammunition; (b) second reserve of small-arm ammunition; (c) saddlery and harness; $(d)$ spare tents ; (e) spare carriages for all arms.

2. The Clothing Train (this might, perhaps, form part of the Storo Train), with similar supplies to the Regimental Train.

3. The Enginecr Reserve Train.

4. The Paymaster's Train.

5. The Medical Train, with all the medicines and appliances required to replenish regimental consumption and losses, and to establish temporary general hospitals in the erent of an engagement.

6. The Commissariat Train.

The Trains above detailed ( 1 to 5 ) should always bo kept up, and the wargons be more or less ready packed, ou a plan based upon the wants of a regiment or battery. This portion of the trainwhich for the sako of distinction we will call No. 1-should be that 
which would move with the column to which it might bo attached. The train to supply it with stores and ammumition, as expended, should consist, as must erer bo the case, of the civilian transport arailable at.the theatro of war, such as railways, carts, mules, or water carriage. No great difficulty could be experienced in fixing upon the amount of carriage required for No. 1 train, so as to enable a forco to fight one or two battles without replenishing.

Commissariat Train.-To estimate tho transport required by the Commissariat Department is a moro difficult problem. The daily necessity of supplying food and fucl, and that bulky requisite, forage, and their collection from the neighbourhood, or transport from tho depots in tho rear to tho point of issue, depending on inconstant data and varying circumstauces, render oren an approximate calculation uncertain. It may, therefore, bo assumed that even No. 1 Commissariat Train rould, on war breaking out, bo supplemented moro or less by contractors' and rendors' carts.

Tho Regimental Trains could always, when the men wero encamped and their waggons consequently cupty, convey their supplies from the Commissariat point of issue to the respectivo camps. If necessary, a special or spare waggon might be used for that purpose. In brigade, regiments should furnish one waggon or moro daily, in turn, for the use of the whole brigado.

Paymaster's Department Train.-The strength of the Paymaster's train would vary with the nature of the monoy in circulation. Eren if the latter consisted principally of gold or notes, a considerable sum would have to be in small coin, to meet the wants of the soldiers. In the United Kingdom this train might, from the facilities of obtaining money, be clispensed with, provision, of course, being mado for tho office books.

All theso departments-essential as they are for the efficiency, and even the existence of tho Army-require men of business, and not military men, to ensure the objects for which they are created. They should, therefore, be strictly civil in their nature. And here another difficulty presents itself - Who is to have the control and authority over the different trains? This is a question not easily auswered, for if the men composing them were soldiers, how would military discipline and order bo maintained?

That each department-especially the Commissariat-ought to have control orer tho whole of its own duties, both in collecting and delivering its supplies, cannot be doubted. If its Officers were to have the whole responsibility they would bo moro independent, more punctual, and efficient; they could timo and arrange thcir measures so as best to meet tho varying difficulties they would constantly have to encounter; and while much correspondence would be saved, the issue of food and forage would be far more satisfactory in the long run, than if the duty of delivery were performed by a separato branch of the Service. These remarks apply in a less degree to the other departments.

Assuming that the horses, or oxen, waggons, and harness (the two latter of the plainest pattern), would be in the charge of the different departments, it only remains to provide tho drivers. 
Drivers.-To meet this difficulty there would appear only one or two ways. One would be to have a corps of drivers, under Officers and Non-commissioned Officers, subject to the Articles of War, but non-combatant. These men should drive, or walk, but not ride; . they should bo dressed in a simple working suit; be bound to help load or unload; and make themselves gencrally useful. In time of war they should bo armed with a revolver only. 'Though they would bo quite distinct from the Army, discipline should be maintained on the Army system. The detachment of these men required by a department for No. 1 train, would bo under an Officer or Non-Commissioned Officer, according to its strength; the Officers, Non-commissioned Officers, and men, while so employed, being bound to obey the head of the department to which they were attached. In fact, the corps should be a body of useful, willing, working men, not above their work, with nothing whatever of the Dragoon about them-as unlike the present Military Train as light is to darkness. To compensate the Officers and men for their anomalous position in a military point of view, it would be necessary to pay them woll. They should only be taught to drive, park, and pack their waggons-no drill or instruction beyond this would be necessary. The Officers, of whom there need be few, should be mounted. Non-commissioned Oflicers should drive, walk, or have a seat on the rear waggon, or, when there were more than one, on the front and rear waggons of the portion of the train in their charge. Such a corps should not consist of volunteers from other regiments, as thcy would at once bring into it the military element, which from its very nature and duties would be objectionable. $\Lambda$ few sensible Noncommissioned Officers (who should be made thoroughly to understand that they would, on joining the corps, have to relinquish much of their "smartness"), might be necessary at first, to establish the interior economy of tho barrack-room. Such a body in time of peace would probably be only a skeleton corps, but, the duties being simple, no difficulty would be found in augmenting it on very short notice, as the trained men would soon instruct the recruits. Jien might bo enlisted for such a corps for short periods, tho pay being a sufficient inducement.

The other plan would be to have a similar corps under the command of the Officers, clerks, and issuers of the Supply Departments. These men, being simply drivers, would be interchangeable among the departments, according to the requirements of the different trains. Their distribution would be determined by the Transport-Director and Quartermaster-General's department. If, however, it should be considered advisable to keep the supply departments distinct, and completo in every respect, then each corps should have its own body of drivers. If the extra work thus entailed were not an insuperable objection, either of the plans, but especially the last, would probably prove the most efficient in practice, as each department, being complete and independent, all collision of authority would ve avoided. It would also assimilate with tho regimental system already proposed.

Transport Directors. - Wo have now provided for the regimental and departmental trains. Toavoid confusion on the line of march, it would 
be necessary to place them in charge of an executive Officer. With a large train, Brigade, Divisional, and Corps Transport-Directors would be required. The senior of these Officers with the force, would receive his orders direct from the Quartermaster-General's Department. Being invested with supreme authority during the march, he would be responsible for tho correct movement of the whole. Officers so employed would requiro considerable tact and ability to deal efliciently with rival interests; and, while enforcing strictly the rules and customs necessary to secure the uninterrupted movement of the trains, ought to have the power as well as the judgment to know when to relax them. If a special and separate corps of drivers were established, the above duties would devolve on the Officers of that corps. The TransportDirectors should alone have the power to halt lor move the line of waggons; the Officers commanding the escorts liaving nothing to do beyond defending them in case of attack.

No. 2 Train.-The train communicating with No. 1 and the base should be organized on a similar plan, but, with the exception of the Transport-Directors, should consist of civilians hired for the time being. It is not much more difficult to bring up stores and supplies for an Army than for a large city, as long as the communications are not threatened or attacked.

In the United Kingdom and in many other countries, the second train would be furnished by the railways; the regimental and No. 1 trains would be able to bring the supplies up to the front from the depôts established at the railway stations.

Summary.-We thus have a transport system, where the regimental trains, driven by soldicrs only, would be employed with the troops in the presence of the enemy, or where military discipline is most required; behind them would come the departmental trains, and their disciplined non-combatant drivers, while in the rear of all, and out of danger, would bo No. 2 train, manned by civilians.

Each train while in camp would be comparatively independent, and at the disposal of the regiment or department to which it belonged. On the line of march all would be under the Transport-Directors. Thus would be combined tho advantages in camp, which a certain amount of freedom would give, with the order and discipline on the line of march absolutely requisite to ensure the unbroken progression of the whole.

Districts.-Reverting to the defence of this country it would be necessary to re-divide the whole kingdom with reference to the railway system, into military districts, to be placed under General Officers, who should command the whole of the troops, both regular and reserve. The head-quarters and a fortified magazine should be at or near the chief railway station, or at an important junction, connected, if necessary, by a branch with the main line. At this secure point all the transport and stores for No. 1 Train of the regular troops, and the stores for the rescrves of the district, should be accumulated, as well as a sufficient supply of all equipment, to make good regimental losses; breakages, and expenditure. 
About eight or ten districts in Great Britain, and four in Ireland, would probably suffice. These being in direct communication with the Government arsenals, would be casily kept supplied with all the stores required. The districts shonld bo so arranged that each should include a portion of the sea-bonrd. Suppose, for example, that England were divided by radial lines, following the boundaries of counties, drawn from a point near Tamworth to the coast; or, for simplicity's sake, into four, by two lines, ono from Hawick in the north to Southampton in the south, the other from Milford Haren to Holbeach. The respective head-quarters might be established at or near Chester, York, London, and Gloucester. This, though only intended as an illustration, would give each a portion of the sca-board to guard.

Provision has now been made for the active Army, or first line.

1st Reserve.-The secont line, or first reserve, should be or granized on a similar plan, substituting the agricultural carriage available. All such carriage should be apportioned (a law being enacted for this purpose), to the different Reserre regiments, so that each Commanding Officer should lnow to what farmer or job-master he would have to go for his transport. IIis stores he would obtain from the district mngazine. Somo delay would doubtless occur before the first Reserve would be ready to more, but in the mean time the actire Army would be on the march fully equipped, giving the first Rescrvo ample time to prepare for the field.

2nd Reserve.-A similar scheme would hold good for the second Reserve. The remaining Reservo troops would be cmployed in holding tho fortresses and towns.

Camps.-In the drill-season, regiments, both Regular and Reserve, should assemble at the different camps, and remain under canvas, during the periods allotted to brigado and divisional instruction. The present huts should, as they decay, be removed, and not replaced.

The regular regiments being in possession of transport, should assist the regiments of the Reserve in bringing their camp equipago to and from the railway stations; as it would not be desirable to call upon the agricultural carriage, except in case of danger from invasion. Failing this, one or two permanent buildings might bo constructed at the camps, to hold sufficient camp-equipago to meet the usual summer demands of the Reserve forces.

In order to reduce expenditure, regiments, as a rule, should remain a year in their quarters, and only move out for their summer drills. The annual hire of horses for the regimental trains would not amount to much, provided the moves now so frequent, were limited to the abovo periods.

Whether it would bo advantageous to extend the system proposed for the regiment, by forming a regimental unit, say of a wing, two companies, or cren one, would depend upon tho number of waggons a regiment would require, and the distribution of the equipment.

The more effectually to carry out the above plans, Commanding Officers of regiments should bo relieved of a good deal of their present office work. The returns now rendered should bo revised. All returns and 
accounts of schools, canteens, and recreation-rooms, might stop at the regiment being, if necessary, periodically examined, either at the halfyearly inspection, or by some Officer or Department appointed to supervise the whole of these and analogous institutions.

Departmental Subordinates. $-A$ certain number of men of superior attainments would be required as compounders, issuers, and storemen, for the medical and other departments. Such men should bo subordinate to, and as a rule under the sole authority of the Officers of these departments. There wonld be no occasion to enlist them, simply because they would administer to the wants of the Army. They might be engaged on terms calculated to meet all that could be required of them in their civil capacitics, and yet to secure a due amount of subordination to military authority.

Indeed it would appear advisable to organizo the whole of the subordinates of the Civil Departments on a system adapted to their special duties, rather than on a military basis; the Officers of the respectivo departments being responsiblo for their efficiency, and for the maintenance of such discipline as might be expected and required. There is nothing military in proriding food, clothing, pay, arms, and ammunition for an Army. Even in the treatment of a soldier either for disease or wounds, medical, not military science is required. All such men should thereforo have no arms, except during war, when, in order to meet unforeseen dangers, they should be supplied with a rovolver apiece. $\Delta$ s such emergencies occur so scldom during a man's lifetime, they should not be trained as soldiers, beyond being taught the use of their weapon. It is not worth while to combine in one man two incongruous duties, one which he has to exerciso daily, with another which he may never bo called upon to perform.

Advantages of Proposed Scheme.-Such a schemo fully carried out would entail considerable expenso at the ontset, but it would ensuro proportionate advantages and security.

If, however, the magazines were not fortified, or if thcir defences consisted simply of earthworks, thrown up by the troops, tho outlay would bo almost limited to the cost of the waggons.

The Store Department would be relieved of the main portion of their present charge, and their duties would be appreciably diminished, èspecially at the most critical moment, namely, the first alarm.

Every regiment would at all times bo prepared, without a moment's hesitation, to march out of barracks, ready in every respect for a campaign. The depôt, school, women and children would remain behind. All the private baggago (materially diminished by tho furnishing of barrack-rooms) and impedimenta not required in the field, would be stowed away in one of the spare store-rooms.

On any emergency, a brigade could be told off from a division, a division from a corps, a corps from an army. Particular regiments might be selected if needful. With the exception of the Commissariat, -and they should be fairly ready, - the Supply Departments would at once furnish No. 1 train, simply on being informed of the number of Batteries, Companies of Engimeers, Regiments of Cavalry and Infantry composing the forcc. The waggons would, if the point of assembly 
were distant and approachable by railway, be run on to the railway trucks, starting at once for their destination, or awaiting the order to move. Draft animals would either accompany them, or bo directed to meet them on their aurival at the given point. Here the advantago of having the waggons packed according to the wants of the unit will be at onco apparent.

It would ensure the greatest clasticity, by facilitating the increasing, reducing, or detaching a force, since the order alone would furnish sufficient information for the Officers commanding regiments, and tho heads of departments, without further reference or directions.

It would give great independence in the event of regiments or brigades being cantoned in separate villages, as then the butchers and bakers could act for their own regiments, or, combined, for the brigade.

The troops in each district would be at once able to present a front, and oppose any landing on their sea-board.

Regiments could embark without delay for foreign service. If to take the field, their waggons and draft animals depending on the sceno of operations, would or would not, accompany them. If for an ordinary tour of foreign service, the waggons and animals might be left behind, and their places supplied on disembarking by a similar set, or by a set adapted to the new station. If, however, mules were the only available means of transport-though the same organization could bo retained-the great increase in the number of animals would necessitate the employment of a certain number of natives, even with the regimental trains.

It would facilitate the instruction of the troops, by enabling them to encamp during the summer drill, freo of all encumbrances, precisely as they would be in active service.

'T'he sum now annually expended in the maintenance of the wooden huts in the respective camps would be sared, and a portion of it would cover all the expenses for the hire of draft animals during the drill season.

The regiments would have the advantage of spending a great portion of the year in towns, instead of in the wooden huts, isolated from the public.

After the harvest, brigades, or divisions of the active Army, could mancuvre over extended areas, encamping in the fields, thus realising and practising the strategical operations incidental to real war.

The division of labour and supervision, obtained by the separation of the regimental and departmental trains, would give to each that individual interest which always tends to real efficiency, and would more than compensate, in practice, for any advantages which might be gained by the centralization of the whole transport in a single department.

The men of the departments being relieved of all parades, care of arms and accoutrements, their whole time would be usefully employed in their special duties. In short, fewer men would be required, and the revolver would meet all that could be required of these as armed men in time of war.

Were the scheme confined to regiments, a most important establish- 
ment would be at once created, as with such a train, without an extra Officer or man, an Army, especially in the United Kingdom, could, on the first outbreat of hostilities, shift for a considerable period, if not altogether.

If the departments were unprovided with waggons, the stores, materials, and implements might still be arranged in the magazines, according to the wants of a regiment, ready to pack on any carriage available.

Conclusion.-In conclusion, though the plan I have ventured to propose may be crude, present many difficulties, have many defects in detail, and be open to criticism, it is submitted that, while in the main simple and practical, it fulfils the conditions set forth in the beginning, namely, those of securing the advantages of constant preparation for war, with all the benefits pertaining to peace. 